\title{
Effect of Rambutan Fruit Peel Extract on Total Sperm Counts of Wistar Rats Induced with High-Fat Feed
}

\author{
Kerin Victoria, Cut Fauziah, Yudhi Nugraha \\ Faculty of Medicine, Universitas Pembangunan Nasional Veteran Jakarta, Indonesia
}

Corresponding author: ynugraha@upnvj.ac.id

\begin{abstract}
Obesity caused by a high-fat diet leads to an altered reproductive hormonal profile, including impaired semen quality. Antioxidants can overcome these conditions. One of the well-known sources of antioxidants is in the rambutan fruit peel extract. This research aimed to figure the effect of rambutan fruit peel extract towards total sperm count in Wistar rats induced with high-fat feed. The study design was used post-test only control group. Subjects were 30 male Wistar rats divided into five groups: Group I (Positive Control) was given high-fat feed, Group II (Treatment Control Group) was given 15mg/kg BW rambutan fruit peel extract, whereas group III, IV, V (Treatment Group) was given an extract of rambutan skin with a dosage of 15,30 , and $60 \mathrm{mg} / \mathrm{kg} \mathrm{BW}$, respectively. Treatment was given for 81 days. This study shows that rambutan fruit peel extract with doses of 15,30 , and $60 \mathrm{mg} / \mathrm{kg}$ BW significantly increase total sperm count in Wistar rats induced with high-fat feed. The outcome using Kruskal Wallis shows a result of p-value 0,010 (CI 95\%). Antioxidant compounds found in rambutan fruit peel extract significantly increase total sperm count in Wistar rats induced with high-fat feed, with the highest efficacy on the dose of $15 \mathrm{mg} / \mathrm{kg}$ BW.
\end{abstract}

Keywords: Fruit Peel Rambutan Extract; Nephelium lappaceum; Obesity; Total Sperm Count

\section{Introduction}

Obesity is a leading health issue throughout the world. Data from the World Health Organization (WHO) presented that the proportion of obesity has tripled from 1975 to 2018. The prevalence of obesity in Indonesia based on data from the Ministry of Health of the Republic of Indonesia (2018) for the age group above 18 years old is $21,8 \%$. The prevalence of obesity has been approximated equivalent to reach all American adults by midcentury if the prevailing trends continue (Chavarro et al., 2010). Obesity caused by multifactorial reasons and occurred due to the accumulation of excessive adipose tissue (Kurdanti et al., 2015). There is a significant health indication related to this state. Elevated body weight has been compared to a higher frequency of conflicting health consequences, among other things such as hypertension, cardiovascular disease, type 2 diabetes, as well as reproductive effects (Chavarro et al., 2010).

Reproductive consequences due to obesity have acknowledged essential thought. The overabundance of body weight in men gradually changes and disrupts the body's physiological function, including fertility abnormality (Chavarro et al., 2010). Infertility represents the failure to conceive and is estimated to affect $19 \%$ of couples of the general population (Ugwuja et al., 2008). The rate of infertility varies from one region to 
the other. In Indonesia, infertility poses a significant social complication affecting 10 $15 \%$ of reproductive-age couples. The main indicator of infertility is semen parameters. Semen parameters are a vital determinant of functional competence of the spermatozoa, including concentration, motility, and morphology. The preeminent reason for the disrupt of the semen parameter is because Teerds, 2011 reported that the accumulation of adipose tissue in individuals before obesity contributes to increases in oxidative chain reactions that produce lipid peroxides resulting in high free radicals. The upsurge of free radicals is regarded as an important factor to DNA damage of the spermatozoa and affects spermatozoa parameters.

Specific diet methods and exercise procedures are applicable for weight loss to prevent weight regain, reduce fat mass in the body, and to prevent reproductive problems. However, the development of traditional diet methods and exercise is often slow and needs a high commitment. Recent studies found that chemically derived from plants are effective in used as herbal medicine. Thus, this herbal medicine has built up the interest of the public for their role in preserve health (Thitilertdecha et al., 2010). Herbal medicine may be an alternative to infertility problems by reducing the accumulation of adipose tissue and free radicals. Rambutan is one of the plants that have potential as an adipose tissue reducer caused by its potent antioxidant activity (Setyawati et al., 2015). Rambutan is a tropical fruit that is widely consumed by the public and left a large amount of public waste because of its peels. A recent study has reported that ethanolic extract of rambutan peel contained flavonoids that can reduce the number of free radicals by blockade the oxidative stress from free radicals and repair the impaired endothelial tissue (Dewanto et al., 2017). Another perspective is also showing good benefits from rambutan isolation and identification. Thitilertdecha et al. (2010) described that the composition from rambutan possessing much greater antioxidants than synthetic antioxidants.

Rompis et al. (2018), stated that obesity is positively correlated with reproductive health, resulting in disruptive in semen analysis. Begin with the previous study, and this present research was held to investigate the use of rambutan fruit peel extract as an alternative therapy in infertility with prior diagnosed with obesity. The principal objective of this article is to find the scientific evidence of the role of rambutan peel extract as herbal medicine to reduce free radicals in impaired semen quality, precisely in total sperm counts.

\section{Material and Method}

\subsection{Sample Source}

The sample used in this study is rambutan peel that appears to be red and ripe obtained from Binjai, Medan, North Sumatera, Indonesia. 


\subsection{Extract Preparation}

The extraction process was done in Badan Penelitian Tanaman Rempah dan Obat (BALITRO), Bogor, Indonesia. Rambutan peel is dried in a drying cabinet, then washed in running water until the dirt (soil, dust) disappears. The next process is drained for up to 2 hours in the sun. Rambutan peel that has been dried smoothed by using a grinder to produce the form of dry powder (simplicial). The powder is then put into a stainlesssteel container to macerate with $96 \%$ ethanol solvent. The macerated process prepared with 3 hours stirred and deposited for at least 24 hours. The collected liquid is filtered using filter paper until it becomes a filtrate. The filtrate is then put into the evaporator glass for evaporation using a rotatory evaporator at $40^{\circ} \mathrm{C}$ for 1,5 hours until a thick extract is gathered.

\subsection{Extract Dose}

Extracts that have been collected from BALITRO were used separately depending on the dose group. The dosage was obtained from Setyawati et al. (2015), according to the study, the rambutan fruit peel extract with a dosage of $15 \mathrm{mg} / \mathrm{kg} \mathrm{Bw}, 30 \mathrm{mg} / \mathrm{kg} \mathrm{BW}$, and $60 \mathrm{mg} / \mathrm{kg} \mathrm{BW}$ effective in increasing leptin and reduce the free radicals contained in obesity rats. The optimum dose within the previous study is $30 \mathrm{mg} / \mathrm{kg}$ BW collected from Inhibitor concentration, showing the free radical scavenging activity as high as $67,50 \%$. The extract was given to rats via a feeding tube. A total of 30 rats were classified into five groups with different treatments: (1) High-fat diet (HFD) (2) Given rambutan peel extract with the dosage of $30 \mathrm{mg} / \mathrm{kg} \mathrm{BW}$ only, (3) High-fat diet treatment with rambutan peel extract with a dosage of $15 \mathrm{mg} / \mathrm{kg}$ BW, (4) High-fat diet treatment with rambutan peel extract with a dosage of $30 \mathrm{mg} / \mathrm{kg} \mathrm{BW}$, (5) High-fat diet treatment with rambutan peel extract with a dosage of $60 \mathrm{mg} / \mathrm{kg}$ BW

\subsection{Animal}

A total of 30 rats wistar strain (Rattus novergicus) were collected from The Faculty of Mathematics and Natural Sciences Institute Technology of Bandung (ITB). Rats were used in-between age 8-12 weeks, weighing from 150-200 grams, and in good condition. The research process starting from rat acclimatization, grouping, and given treatment was done at the Pharmacology Therapy Laboratories, Faculty of Medicine, University of Padjajaran Bandung, West Java, Indonesia with Standard Operating Procedures (SOPs) and right in vitro method practice.

\subsection{Procedure}

All rats were divided into five different treatment group, consisting: (1) High-fat diet (HFD) only, (2) Given rambutan peel extract with a dosage of $30 \mathrm{mg} / \mathrm{kg}$ BW only, (3) High-fat diet treatment with rambutan peel extract with a dosage of $15 \mathrm{mg} / \mathrm{kg} \mathrm{BW}$, (4) High-fat diet treatment with rambutan peel extract with a dosage of $30 \mathrm{mg} / \mathrm{kg} \mathrm{BW}$, (5) High-fat diet treatment with rambutan peel extract with a dosage of $60 \mathrm{mg} / \mathrm{kg}$ BW. The commercially standard diet used was CP551 made by PT Charoen Pokphand Indonesia 
consist of water $14 \%$, protein $21-23 \%$, fat $5-8 \%$, calcium $0,9-1,2 \%$, phosphor $0,7-1 \%$. The high-fat diet (HFD) were given contains $3372 \mathrm{cal} / \mathrm{kg}$ and were made manually in the laboratories consisting of egg yolk, lamb fat, pork belly, margarine, and cow's brain. As for energy contain; protein $20 \%$, fat $77 \%$, carbohydrates 3,0\%. The high-fat diet was given $20 \mathrm{mg} / \mathrm{kg} \mathrm{BW}$, scheduled every 8 AM for 81 days, and are administered through a feeding tube.

Rats were adapted in laboratories for the first seven days by providing a basic diet use water, administered via ad libitum. The rats were classified into distinctive groups. Treatment of a high-fat diet (HFD) was given to selected categories precisely on day eight until day 81 to achieve obesity, according to Lee Index (weighing 250-400 grams). On the 21st day, the treatment was continued by giving ethanolic extract of rambutan fruit peel. The routine procedure for the ethanolic extract of rambutan fruit peel was given every day at $9 \mathrm{AM}$ for 51 days to complete one whole cycle of spermatogenesis.

After 81 days, rats were terminated surgically to remove testicles, cauda epididymis, and distal parts of the vas deferens. Pieces of cauda epididymis were inserted into a petri dish and dropped with three drops of $0,9 \% \mathrm{NaCl}$ solution. Spermatozoa suspension stirred homogeneously and counted with the hemocytometer Neubauer method.

\subsection{Preparation of Animal Testes}

After 81 days, rats were terminated surgically to remove testicles, cauda epididymis, and distal parts of the vas deferens. This procedure was done in Pharmacology Therapy Laboratories, Faculty of Medicine, University of Padjajaran, Bandung, West Java, Indonesia. The surgery is primarily done with anesthesia procedure using ketamine 0,3 cc intramuscular on lateral thighs. After all of the rats sedated, the surgery was proceed and ready to remove the testicles, cauda epididymis, and distal parts of the vas deferens. Pieces of cauda epididymis were inserted into a petri dish and dropped with three drops of $0,9 \% \mathrm{NaCl}$ solution. Spermatozoa suspension stirred homogeneously and counted with hemocytometer Neubauer.

\subsection{Sample Analysis}

The samples were analyzed at Pharmacology and Therapy Laboratories, Faculty of Medicine, University of Padjajaran, Bandung, Indonesia. The integrated sample analyses were executed by the same medical laboratory scientist to dodge inter-laboratory alteration.

\subsection{Sperm Counts}

Sperm counts were determined through cell-counting chambers using the hemocytometer method in following WHO guidelines (Sieme). Semen was proved within 60 minutes of their assortment and represented spermatozoa count per milliliter (count $/ \mathrm{ml}$ ). The preparation formula to begin the sperm count is to classified the sperm 
counted within five small squares then proceed as Ugwuja et al. (2008), Number of sperm counted $\mathrm{x}$ dilution factor (this study using 1:20) x $1000=\mathrm{sperm} / \mathrm{ml}$.

\section{Results and Discussion}

\subsection{Results}

The effects of rambutan (Nephelium lappaceum) fruit peel extract on total sperm counts of white rats (Rattus novergicus) are shown in the graphic figure 1:

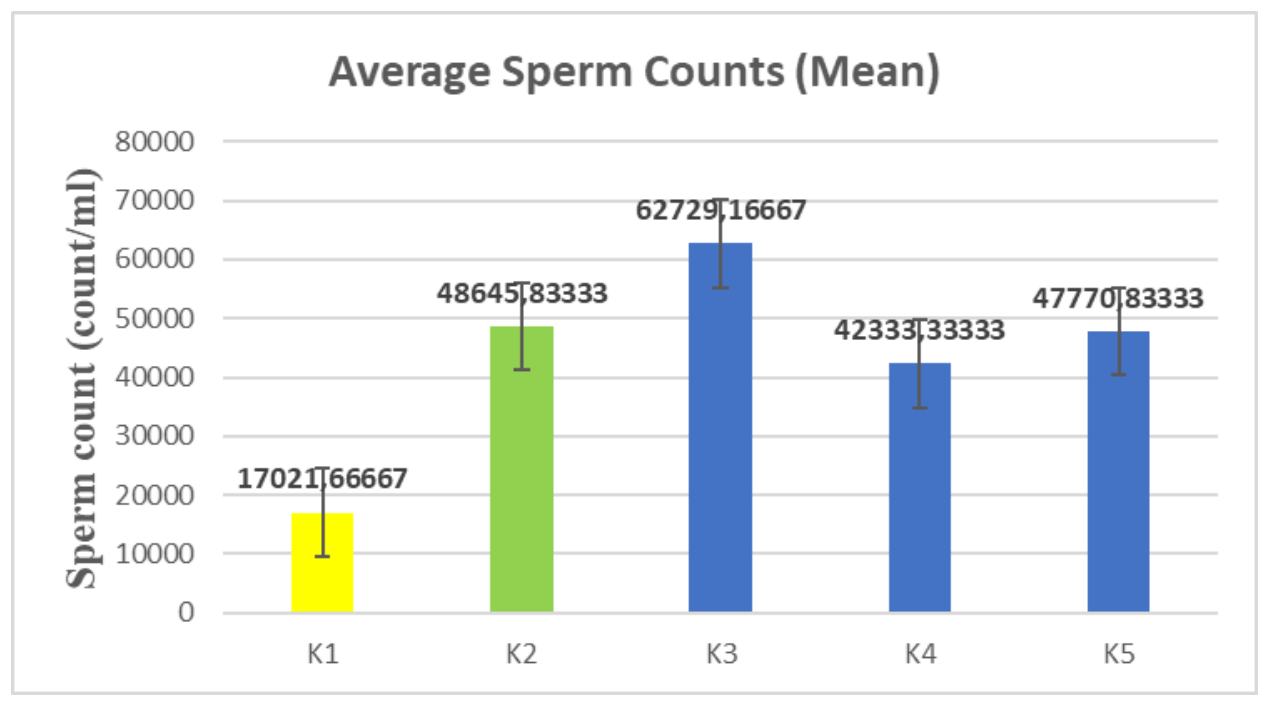

Picture 1. Graphic of average sperm counts (K1= HFD only; K2= rambutan extract with dosage of $30 \mathrm{mg} / \mathrm{kg} \mathrm{BW}$; K3= HFD + rambutan extract with dosage of $15 \mathrm{mg} / \mathrm{kg} \mathrm{BW}$; K4= HFD + rambutan extract with dosage of $30 \mathrm{mg} / \mathrm{kg} \mathrm{BW}$; K5= HFD + rambutan extract with dosage of $60 \mathrm{mg} / \mathrm{kg} \mathrm{BW}$ ).

The graphic above shows increases in total sperm counts after given treatment of rambutan fruit peel extract with a dosage of $15 \mathrm{mg} / \mathrm{kg}$ BW. This result is statistically significance $(p<0,05)$. The lowest effect of rambutan fruit peel extract is shown in group $\mathrm{K} 4$ and $\mathrm{K} 5$, exhibit the result of rambutan fruit peel extract with a dose of $30 \mathrm{mg} / \mathrm{kg} \mathrm{BW}$ and $60 \mathrm{mg} / \mathrm{kg} \mathrm{BW}$, respectively.

\subsection{Discussion}

Obesity associated with irregular hormone control that can lower the quality of spermatozoa. Martini (2012) reported that men with obesity have much lower active sperms than a man with normal body weight. This study state that in obese condition, there will much likely be a reduction in sperm quality. Rompis et al. 2018, compared a control group (normal rats were given normal diet; 20 gram of food per day for 50 days) with treatment group (diet-induce obesity rats given 22 gram of food per day for 50 days) shows that control group exhibit a higher sperm count, 112,4 x $10^{6} \mathrm{sperm} / \mathrm{ml}$ than the treatment group (diet-induced obesity), resulting in $48,6 \times 10^{6} \mathrm{sperm} / \mathrm{ml}$. According to the previous study, it is concluded that obesity has lower sperm counts. This data is 
included in this present study, the group of rats given a high-fat diet (HFD) resulting in $17.021,66$ sperm counts, showing a decrease in total sperm counts compared to normal sperm count in the previous study.

Obesity is a condition caused by unbalanced energy consumed to maintain homeostasis. Obesity induces an increasing level of adipose tissue by which mechanisms are energy expenditure is lower than energy intake, resulting in the accumulation of fat. Accumulation of fat will point to hypertrophy and hyperplasia of adipose tissue. Increases of adipose tissue will trigger stress induce reaction because of obesity is categorized as chronic low-grade inflammation (Susantiningsih \& Mustofa, 2018), causing unbalance in leptin production. Leptin, an adipocytokine hormone produce by adipose tissue, is responsible for the management of reactive oxygen species and triggers cytokine pro-inflammation; TNF and Interleukin 6 (Limanan \& Prijatin, 2013). Hoda et al. (2012) reported that circulated leptin in-normal weight person is $1-3 \mathrm{ng} / \mathrm{ml}$; meanwhile, circulated leptin in obesity is $100 \mathrm{ng} / \mathrm{ml}$. This study reveals that a high leptin level in obesity is correlated with decrease performance of leptin to reduce food intake, gaining weight, or a condition called leptin resistance. Another study revealed that high-fat feed continuously triggers oxidative stress due to the disproportion of prooxidant and antioxidant endogen (Susantiningsih \& Mustofa, 2018).

Spermatozoa cell membrane consists of polyunsaturated fatty acids (PUFA) that work to get in touch with oocyte and provide oocyte fusion. The appearance of free radicals due to chronic low-grade inflammation manage to harm the normal cell of spermatozoa. This condition happens because reactive oxygen species responsible for gonad cell degeneration furthermore affects spermatogenesis (Sharma et al., 2013). The result of this study emphasizes the experiment supervised by Shukla et al., (2014) that obesity affects the quality and quantity of spermatozoa. This condition will further be noticed through sperm parameters consist of sperm motility, sperm morphologic, and testosterone levels.

Palmer et al. (2012) state that individuals with obesity have interaction between adipose tissue and hormone regulation that disturb sperm parameters, along with concentration, motility, and morphology of spermatozoa. Rompis et al. (2018) reported that control group/ $\mathrm{P}_{0}$ (normal rats were given normal diet; 20 grams of food per day for 50 days) compared with treatment group/ $\mathrm{P}_{1}$ (diet-induce obesity rats given 22 grams of food per day for 50 days) shows a significant result. Those with treatment groups were categorized into group motility A, B, C, and resulting in lower sperm motility; $12,8 \%$, $44,4 \%$, and $42,4 \%$, respectively. Meanwhile control group $\left(\mathrm{P}_{0}\right)$ was categorized into group motility A with $21 \%$ of sperm motility, group B with $64 \%$ sperm motility, and group $\mathrm{C}$ with $15 \%$ sperm motility.

Morphology tests for sperm analysis were categorized into normal morphology and abnormal morphology. Rompis et al. (2018) reported a result with group control $\left(\mathrm{P}_{0}\right)$ resulting in $71,6 \%$ normal morphology compared with group treatment $\left(\mathrm{P}_{1}\right)$ with $55,2 \%$. As for the abnormal morphology categories, the control group $\left(\mathrm{P}_{0}\right)$ shows a 
lower percentage; $28,4 \%$ compared to the treatment group ( $\left.\mathrm{P}_{1}\right)$ with $44,8 \%$. This result correlates with Hofny et al, 2010 that obesity affects sperm quality in terms of motility and morphology of normal spermatozoa. This condition leads to normal sperm apoptosis and later on leads to decrease sperm count due to decline energy by mitochondrial damage of the sperm (Sharma et al., 2013).

Published data from Teerds et al., 2011 also confirmed the relationship between obesity and reduced testosterone. It is happening because there is disfunction in endocrine status. The cutback in testosterone levels is bound to happen because of a decline in sex-hormone-binding globulin levels in obese individuals, thus making testosterone is accessible to be transformed into estrogens in fat tissue. The effect of rambutan fruit peel extract in increasing total sperm count is predicted due to the high content of flavonoids and polyphenols (Dewanto et al., 2017). Flavonoids can increase sperm count by inhibiting the oxidative chain reaction in the initiation and propagation phase. Polyphenols are categorized as a natural phytochemical that is essential to inflict physiological and molecular pathways participating in the metabolism of energy, adiposity, and obesity. Compatible in vivo study shows the valuable effects of polyphenols by acting as integral agents through the mechanism of up-regulation of energy expenditure (Meydani, 2010). The ability of rambutan fruit peel extract to increase total sperm count in this study is shown best with a dosage of $15 \mathrm{mg} / \mathrm{kg} \mathrm{BW}$. This result is related to the antioxidant compound that presents in rambutan fruit peel extract. Flavonoid acts as an electron $\mathrm{H}+$ group donor and reduces reactive peroxidative chains to produce a more stable radical oxidant.

Thitilertdecha et al. (2010) stated the identification of antioxidant activity. From the prior experiment, the antioxidant activity was conducted, proving a lipid peroxidation inhibition assay and chromatography Sephadex LH-20. The outlying composition was found as ellagic acid, corilagin, and geranin, thus show the extravagant amount of antioxidant activities than butylated hydroxytoluene (antioxidant synthetic) in both lipid peroxidation and DPPH (diphenyl-2-picrylhydrazine) scavenging assays. A previous experiment concludes that antioxidants contained in rambutan could be further utilized as medicine. Statistical analysis $(p<0,05)$ showed that it is significantly different between group (1) given high-fat diet (HFD) and treatment group with different dosage of rambutan fruit peel extract (high-fat feed with extract with a dosage of $15 \mathrm{mg} / \mathrm{kg} \mathrm{BW}, 30 \mathrm{mg} / \mathrm{kg} \mathrm{BW}$, and $60 \mathrm{mg} / \mathrm{kg} \mathrm{BW}$ ). This concludes that there is a significant difference among treatment groups. Thus, meaning the given treatment of rambutan fruit peel extract increasing sperm counts.

Based on the data, group (1) given a high-fat diet (HFD) has the lowest sperm count. That was explained in a previous study that diet-induced obesity positively correlates with abnormalities in sperm analysis (Rompis et al., 2018). Meanwhile, groups with given different dosages of rambutan fruit peel extract showing higher sperm count, with the greatest efficacy, are the dosage of $15 \mathrm{mg} / \mathrm{kg} \mathrm{BW}$. From this study, it is concluded that the best efficacy of increasing sperm count is rambutan fruit peel 
extract with a dosage of $15 \mathrm{mg} / \mathrm{kg}$ BW. This show a different result from other higher dosage (30mg/kg BW and $60 \mathrm{mg} / \mathrm{kg}$ BW). Setiyawati et al. (2015) reported that rats given higher dosage show a significant result in circulated leptin, resulting in inhibition effect on leptin transport through the blood-brain barrier to the hypothalamus and inhibit leptin binding to the leptin receptor in the hypothalamus. This condition leads to unable leptin to suppress the food craving, furthermore resulting in higher food consumption and wider the inflamed location and increasing reactive oxygen species. Mahmudah et al. (2018) also, stats that a dosage of $60 \mathrm{mg} / \mathrm{kg} \mathrm{BW}$ is a toxic dose that can cause an adverse effect by producing more free radicals that can enter the hepatic cell and leads to cell disruption. This condition resulting from the glutathione in liver failure to binds to make covalent bonds with toxic substances around to make the substances less toxic, so more glutathione leads to more stress oxidative in cell and thus presenting in abnormalities in cellular respiration in mitochondria and exhibit freer radical produced. These benefits of rambutan fruit peel extract may become an assuring alternative therapy solution for fighting with free radicals and obesity.

\section{Conclusion}

In conclusion, our study shows that rambutan fruit peel extracts significantly increase total sperm counts in obese rats with an effective dosage of $15 \mathrm{mg} / \mathrm{kg}$ BW.

\section{References}

Chavarro, J. E., Toth, T. L., Wright, D. L., Meeker, J. D., \& Hauser, R. (2010). Body mass index in relation to semen quality, sperm DNA integrity, and serum reproductive hormone levels among men attending an infertility clinic. Fertility and Sterility, 93(7), 2222-2231. https://doi.org/10.1016/j.fertnstert.2009.01.100

Hoda, M. R., Theil, G., Mohammed, N., Fischer, K., \& Fornara, P. (2012). The adipocytederived hormone leptin has proliferative actions on androgen-resistant prostate cancer cells linking obesity to advanced stages of prostate cancer. Journal of Oncology. https://doi.org/10.1155/2012/280386

Hofny, E. R. M., Ali, M. E., Abdel-Hafez, H. Z., Kamal, E. E. D., Mohamed, E. E., Abd ElAzeem, H. G., \& Mostafa, T. (2010). Semen parameters and hormonal profile in obese fertile and infertile males. Fertility and Sterility, 94(2), 581-584. https://doi.org/10.1016/j.fertnstert.2009.03.085

Kurdanti, W., Suryani, I., Syamsiatun, N. H., Siwi, L. P., Adityanti, M. M., Mustikaningsih, D., \& Sholihah, K. I. (2015). Faktor-faktor yang mempengaruhi kejadian obesitas pada remaja. Jurnal Gizi Klinik Indonesia, 11(4), 179-190. https://doi.org/10.22146/ijcn.22900

Limanan, D. \& Prijati, A. R. (2013). Hantaran sinyal leptin dan obesitas: hubungan dengan penyakit kardiovaskular. EJurnal Kedokteran Indonesia, 1(2), 144-155. https://doi/org/10.23886/ejki.1.2063 
Mahmudah, A., Tenzer A., \& Lestari S. R. (2018). Pengaruh Ekstrak Kulit Buah Rambutan (Nephelium lappaceum L) Terhadap Nekrosis Sel Hepar Tikus (Rattus novergicus) Obesitas. Bioeksperimen: Jurnal Penelitian Biologi, 4(1), 48-52. https://doi.org/10.23917/bioeksperimen.v4i1.5931

Martini, F. (2012). Fundamentals of Anatomy and Physiology (Benjamin C). Washington DC.

Meydani, M. \& Hasan S. T. (2010). Dietary polyphenols and obesity. Nutrients, 2(7), 737751. https://doi.org/10.3390/nu2070737

Palmer, N. O., Bakos, H. W., Fullston, T., \& Lane, M. (2012). Impact of obesity on male fertility, sperm function, and molecular composition. Spermatogenesis, 2(4), 253263. https://doi.org/10.4161/spmg.21362

Rompis, S. A., Tendean, L. E. N., \& Rumbajan, J. M. (2018). Pengaruh Kelebihan Berat Badan terhadap Kualitas Spermatozoa Tikus Wistar (Rattus Norvegicus). Jurnal EBiomedik. 6 (1), 39-44. https://doi.org/10.35790/ebm.6.1.2018.18769

Setyawati, A., Dewi, A. K., Atho'illah, M. F., Lestari, U., \& Lestari, S. R. (2015). The Effect of Rambutan (Nephelium lappaceum L.) Peel Extract on Lipid Peroxidation in Liver of Obese Rats. In KnE Life Sciences. 2, 326. https://doi.org/10.18502/kls.v2i1.167

Sharma, R., Biedenharn, K. R., Fedor, J. M., \& Agarwal, A. (2013). Lifestyle factors and reproductive health: Taking control of your fertility. Reproductive Biology and Endocrinology, 11(1), 1-15. https://doi.org/10.1186/1477-7827-11-66

Shukla, K. K., Chambial, S., Dwivedi, S., Misra, S., \& Sharma, P. (2014). Recent scenario of obesity and male fertility. Andrology. 2(6), 809-818. https://doi.org/10.1111/andr.270

Teerds, K. J., de Rooij, D. G., \& Keijer, J. (2011). Functional relationship between obesity and male reproduction: From humans to animal models. Human Reproduction Update, 17(5), 667-683. https://doi.org/10.1093/humupd/dmr017

Thitilertdecha, N., Teerawutgulrag, A., Kilburn, J. D., \& Rakariyatham, N. (2010). Identification of major phenolic compounds from Nephelium lappaceum L. and their antioxidant activities. Molecules, 15(3), 1453-1465. https://doi.org/10.3390/molecules15031453

Ugwuja, E. I., Ugwu, N. C., \& Ejikeme, B. N. (2008). Prevalence of low sperm count and abnormal semen parameters in male partners of women consulting at infertility clinic in Abakaliki, Nigeria. African Journal of Reproductive Health, 12(1), 67-73. https://doi.org/10.2307/25470635. 